\title{
Współpraca szkoły ze środowiskiem lokalnym
}

\author{
„Piękno tej Ziemi skłania mnie \\ do wolania o jej zachowanie \\ dla przysztych pokoleń. \\ Jeżeli kochacie tę ojczystą ziemię, \\ niech to wotanie nie pozostanie \\ bez odpowiedzi!" \\ Ojciec Święty Jan Pawel II
}

Każdy człowiek korzystając ze środowiska przyrodniczego otrzymuje surowce naturalne, energię, a także czerpie również inspiracje wypływające z piękna natury. Niestety, nie każdy zdaje sobie sprawę, jaki wpływ na stan środowiska ma zachowanie poszczególnych jednostek ludzkich, rodzin czy grup społecznych. Duży wpływ na zmianę stanu środowiska mają także przyzwyczajenia, styl życia, sposoby wypoczynku jak również odżywianie i inne działania podejmowane każdego dnia przez człowieka.

„Zagrożenie środowiska przyrodniczego stało się faktem”. Jedynie wspólny wysiłek wszystkich ludzi razem i każdego $z$ osobna, podejmowany codziennie jest w stanie zahamować degradację środowiska. „Skalę zagrożeń środowiska uświadamia sobie coraz więcej ludzi, zdają sobie $z$ tego sprawę liczne organizacje międzynarodowe i dają temu wyraz, poszukując nowych metod renowacji i ochrony środowiska."

Podstawową jednostką samorządu terytorialnego jest gmina, w której powstają wszystkie pomysły dotyczące ochrony środowiska oraz te, które właśnie tam zaczynają się rozwijać. „Najważniejszą władzę w gminie stanowi ogół jej mieszkańców, który wyjawia swoją wolę bezpośrednio w głosowaniu powszechnym, albo za pośrednictwem organów gminy."3

1 D. СІснy, Szkola ekologiczna. Funkcjonowanie i perspektywy rozwoju. Fundacja Centrum Edukacji Wsi w Krośnie. Krosno 1996, s. 7.

2 D. CICHY, Szkola ekologiczna. Funkcjonowanie i perspektywy rozwoju. Fundacja Centrum Edukacji Wsi w Krośnie. Krosno 1996, s. 7.

3 В. Розквовко, Zarządzanie środowiskiem. Polskie Wydawnictwo Ekonomiczne, Warszawa 1998, s. 162. 
Organem stanowiącym i kontrolnym, przez który gmina realizuje swoje plany i zadania jest rada gminy, a organem wykonawczym - zarząd gminy.

Zadania rady gminy są wyraźnie określone:

- powoływanie stałych i doraźnych komisji,

- przedkładanie planu pracy rady gminy,

- sprawozdania z jej działalności.

Zarząd gminy również ma swoje określone działania. „Zarząd gminy wykonuje zadania gminy za pomocą urzędu gminy."

Ochroną środowiska zajmuje się nie tylko urząd gminy. Zadania z tego zakresu realizowane są również przez różne formalne i nieformalne jednostki organizacyjne.

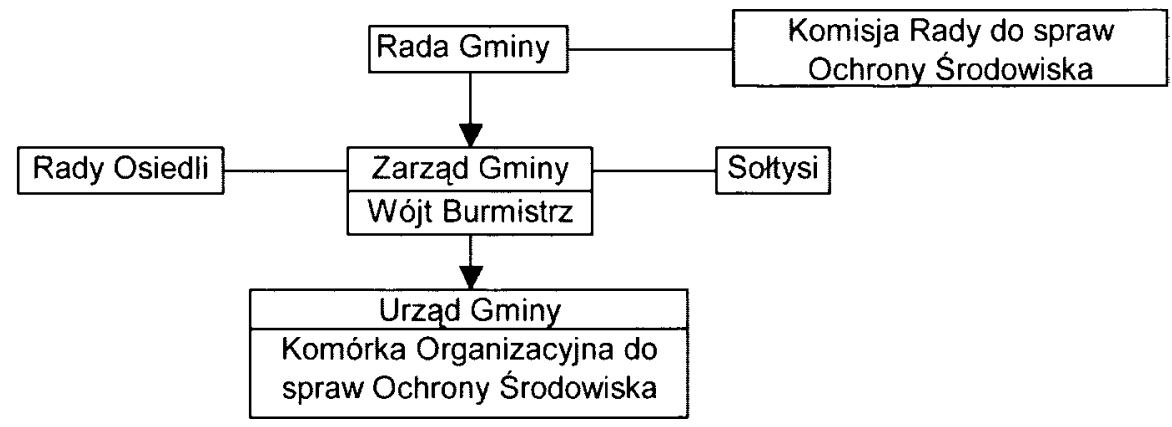

Schemat nr 1. Struktura samorządu terytorialnego [źródto:] Poskrobko B. 1998:

Zarzadzanie środowiskiem. Polskie Wydawnictwo Ekonomiczne Warszawa s. 163

Przewodniczącym zarządu gminy jest wójt, burmistrz lub prezydent miasta, którego zadaniem jest kierowanie bieżącymi sprawami w swojej jednostce terytorialnej oraz reprezentacja jej na zewnątrz.

„Realizacja programów zrównoważonego rozwoju gmin wymusza potrzebę skutecznych działań administracyjnych dla egzekwowania wymogów środowiska. Obok instrumentów administracyjnych, prawnych i ekonomicznych, niezbędne jest kształtowanie świadomości społeczeństwa o osobistej odpowiedzialności każdego obywatela za właściwe korzystanie z zasobów i walorów środowiska przyrodniczego. ${ }^{5}$

Pożądany stan środowiska można osiągnąć poprzez odpowiednie jego użytkowanie, ochronę i kształtowanie. Wiele problemów związanych $\mathrm{z}$ degradacją środowiska, mimo iż są one charakterystyczne dla różnych społeczności, można określić jako lokalne.

4 B. Posкroвко, Zarzadzanie środowiskiem. Polskie Wydawnictwo Ekonomiczne, Warszawa 1998, s. 163.

5 K. DUBEL, Inwentaryzacja przyrodnicza gmin w programach ekorozwoju, [w:] Ekorozwój w gminie. Red. Gumińska M. Towarzystwo Naukowe Sandomierskie, Sandomierz 1996, s. 33. 
„Proces zarządzania środowiskiem w gminie wymaga uwzględnienia oczekiwań oraz wkładu (pozytywnego i negatywnego) czterech jego uczestników:

- mieszkańców,

- przedsiębiorców,

- grup interesu (jednostkowego, społecznego lokalnego i społecznego ponadlokalnego),

- a także instytucji i urzędów rządowych.” - schemat nr 2.

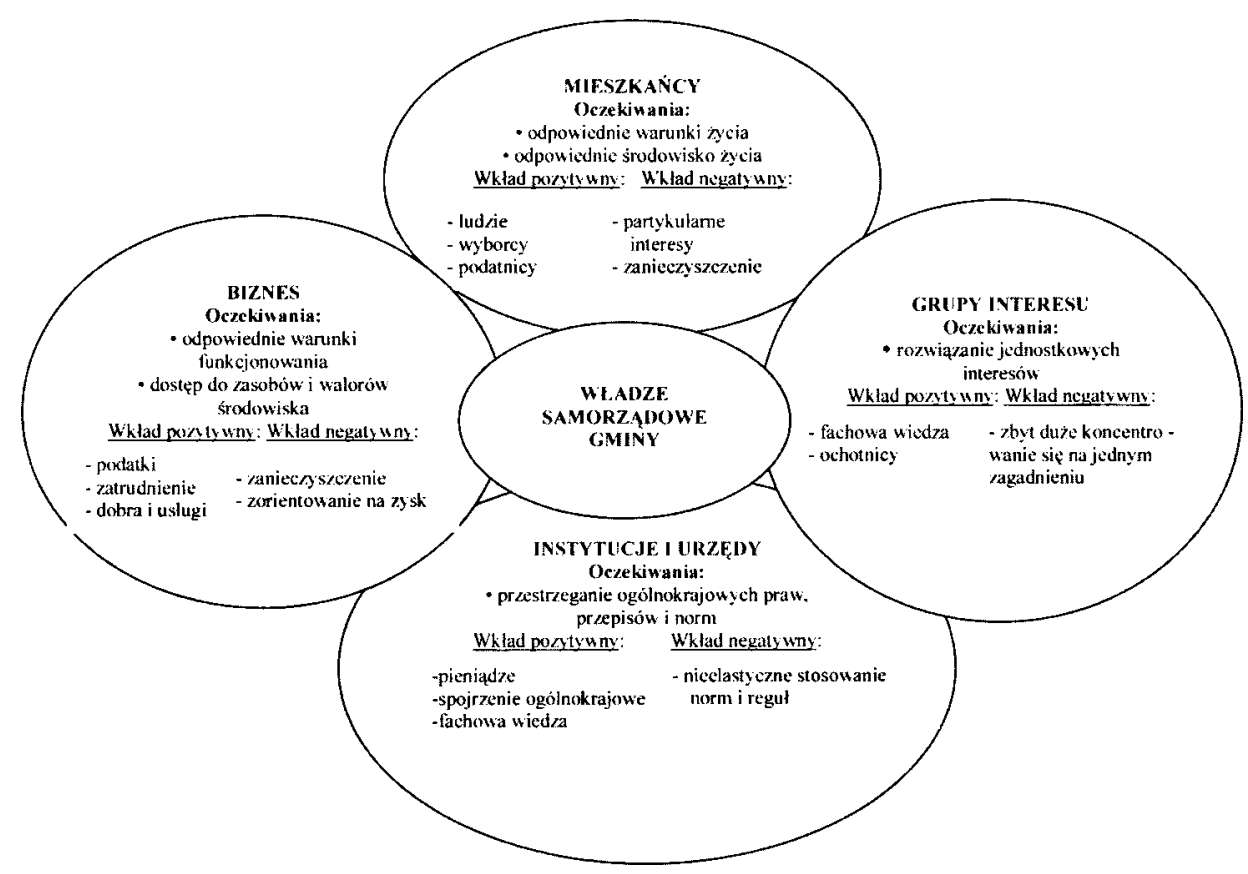

Schemat nr 2. Oczekiwania i wkład uczestników zarządzania środowiskiem, [źródto:] Poskrobko B. 1998: Zarzadzanie środowiskiem. Polskie Wydawnictwo Ekonomiczne Warszawa s.346

W Polsce większość gmin ochronę i kształtowanie środowiska traktuje jako jedno $z$ bieżących zadań w działalności samorządu i urzędu. „Podejście takie nie sprzyja ekologicznej, gospodarczej i społecznej racjonalności działania. Wcześniej czy później wszystkie gminy wdrożą określone systemy zarządzania środowiskiem.

6 B. Pоsкrовко, Zarządzanie środowiskiem. Polskie Wydawnictwo Ekonomiczne, Warszawa 1998, s. 345. 
Istnieją dwie drogi dochodzenia do tego celu:

- wybór konkretnego systemu zarządzania środowiskiem w gminie i jego wdrożenie zgodnie z przyjętymi procedurami,

- wdrożenie procedur rozpoznawczych (podstawowych), a następnie wybór jednego z systemów zarządzania środowiskiem."7

Gminny program ochrony środowiska w Kielcach został opracowany w lipcu 2004 roku i liczy około 270 stron. Cele strategiczne tego programu zestawiono w Tabeli 1.

Tabela 1. Cele strategiczne przyjęte dla „Programu ochrony środowiska dla miasta Kielce” (www.um.kielce.pl/środowisko s.263).

\begin{tabular}{|l|l|l|}
\hline Lp. & \multicolumn{1}{|c|}{ Priorytet } & \multicolumn{1}{|c|}{ Cel strategiczny } \\
\hline 11. & $\begin{array}{l}\text { Ochrona wód po- } \\
\text { wierzchniowych }\end{array}$ & $\begin{array}{l}\text { Osiąganie dobrego stanu ekologicznego wód pod wzglę- } \\
\text { dem ilościowym i jakościowym. }\end{array}$ \\
\hline 22. & Jakość powietrza & $\begin{array}{l}\text { Zmniejszenie i utrzymanie substancji w powietrzu, co } \\
\text { najmniej na dopuszczalnym poziomie. }\end{array}$ \\
\hline 33. & Poważne awarie & $\begin{array}{l}\text { Stworzenie skutecznego systemu zapobiegania poważ- } \\
\text { nym awariom oraz zmniejszenie negatywnych skutków } \\
\text { dla środowiska w przypadku ich wystąpienia. }\end{array}$ \\
\hline 44. & Zieleń & $\begin{array}{l}\text { Utrzymanie przewagi terenów zielonych nad obszarami } \\
\text { zabudowy jako warunku zrównoważonego rozwoju. }\end{array}$ \\
\hline 55. & $\begin{array}{l}\text { Hałas i promienio- } \\
\text { wanie elektromagne- } \\
\text { tyczne }\end{array}$ & $\begin{array}{l}\text { Ograniczenie uciążliwości hałasu poprzez obniżenie } \\
\text { jego natężenia w celu zmniejszenia skali narażenia } \\
\text { mieszkańców na nadmierny, ponadnormatywny po- } \\
\text { ziom. } \\
\text { Kontrola i ograniczenie emisji promieniowania elektro- } \\
\text { magnetycznego do środowiska do poziomów dopusz- } \\
\text { czalnych. }\end{array}$ \\
\hline 66. & $\begin{array}{l}\text { Ochrona wód pod- } \\
\text { ziemnych }\end{array}$ & $\begin{array}{l}\text { Ochrona zasobów wód podziemnych i racjonalne ich } \\
\text { wykorzystanie. }\end{array}$ \\
\hline 77. & Bioróżnorodność, lasy & $\begin{array}{l}\text { Ochrona zasobów przyrody w mieście i racjonalne wy- } \\
\text { korzystanie zasobów leśnych wraz z ochroną środowi- } \\
\text { ska leśnego. }\end{array}$ \\
\hline 88. & Gleby i grunty & \begin{tabular}{l} 
Ochrona gleb i gruntów. \\
\hline
\end{tabular} \\
\hline
\end{tabular}

Priorytetowym zadaniem wielu gmin staje się również zwrócenie uwagi na szeroko rozumianą edukację ekologiczną i sozologiczną całej społeczności lokalnej.

Zdaniem Cichy ,edukacja środowiskowa jest obecnie jednym $\mathrm{z}$ istotnych wyzwań współczesnej szkoły. Spełnia bardzo istotną rolę w życiu człowieka, po-

7 В. Розквовко, Zarządzanie środowiskiem. Polskie Wydawnictwo Ekonomiczne, Warszawa 1998 , s. 348. 
nieważ pozwala poznać potrzeby ludzkiego organizmu oraz stwarza warunki do prawidłowego jego rozwoju. Ma również niebagatelne znaczenie w zakresie stosunku człowieka do środowiska.

Wiedza o środowisku, którą uczniowie nabywają przed wejściem w dorosłe życie jest niezwykle istotna. Ważny jest podstawowy zasób wiadomości i praktycznych umiejętności, a także nawyków i postaw, które pozwolą na właściwe funkcjonowanie młodych ludzi w szeroko pojętym środowisku. Koniecznym elementem współczesnej edukacji jest odpowiednie przygotowanie uczniów do podejmowania racjonalnych działań służących ochronie przyrody, poprawie stanu środowiska, dostrzegania zagrożeń cywilizacyjnych oraz rozwiązywania problemów stwarzanych w środowisku przez człowieka. Edukacja środowiskowa stanowi jedno z globalnych wyzwań ludzkości. Cały świat odczuwa skutki cywilizacji i nadmiernej ingerencji czlowieka w podstawowe procesy ekologiczne."

Dlatego obowiązkiem władz szkolnych jest umożliwienie wszystkim kształcącym się, poznanie podstawowych praw przyrody i zasad prawidłowego funkcjonowania w środowisku.

Ks. prof. J.M. Dołęga uważa, że „edukacja środowiskowa - to słowo, coraz powszechniej używane w szkolnictwie, oznacza wszystko, co niesie w swojej treści wyrażenie: edukacja ekologiczna i edukacja sozologiczna oraz pewne aspekty samego terminu szeroko rozumianego środowiska. Dlatego edukacja środowiskowa zawiera w swojej treści następujące aspekty: biologiczny, abiotyczny, sozologiczny i społeczny."

Kształceniem środowiskowym należy objąć również dorosłych i powinno ono odbywać się także przez samokształcenie. Warto więc zwiększyć oddziaływanie środków przekazu takich jak: telewizja lokalna, prasa, książka.

Kształcenie środowiskowe dorosłych powinna cechować:

- różnorodność organizacyjna,

- ciągłość kształcenia,

- wielopoziomowość form, metod i środków edukacji,

- elastyczność,

- drożność pomiędzy różnymi formami i ogniwami kształcenia,

- przystępność systemu kształcenia,

- ogólne rozpowszechnienie i dostępność.

8 D. СІсну, Zmiany w edukacji biologicznej $i$ środowiskowej $w$ szkołach ponadgimnazjalnych. Edukacja Biologiczna i Środowiskowa. 1. s. 45-48.

9 J.M. DoŁf̨GA, Zamiast wprowadzenia. [w] Problemy XXI wieku prawo ochrony środowiska, edukacja środowiskowa i agrobiznes. Czartoszewski J.W.; Grzegorzewicz E.; Świderski A.W. Wydawnictwo Uniwersytetu Kardynała Stefana Wyszyńskiego, Warszawa 2005, s. 8. 
Należy dążyć, aby edukacja środowiskowa dorosłych nie ograniczała się wyłącznie do funkcji dydaktycznej, ale by zdobywane w jej toku wiadomości znajdowały zastosowanie bezpośrednio $w$ praktyce, $w$ realizowanych inwestycjach proekologicznych. ${ }^{10}$

Współczesna szkoła powinna być nie tylko miejscem nauczania, ale również wychowania. W pracy z dziećmi i młodzieżą można liczyć na ich zapał i zaangażowanie, które zostaną przeniesione na dom rodzinny. Jeśli dorośli zostaną zachęceni przez swoje dzieci do aktywnej działalności na rzecz środowiska lokalnego, a wzorce nabyte w szkole przeniesione do domu, to możemy mówić o sukcesie pedagogicznym. ${ }^{11}$

W realizacji edukacji ekologicznej przyjęto następujące priorytety:

1. Włączenie samorządów terytorialnych w proces edukacji ekologicznej poprzez podjęcie dialogu ze społeczeństwem.

2. Dostosowanie form edukacji ekologicznej dla potrzeb różnych grup spolecznych.

3. Włączenie środków masowego przekazu w proces edukacji ekologicznej i propagowanie zdrowego stylu życia.

4. Dostosowanie polityki ochrony środowiska do obowiązującej w UE.

Realizacja opracowanych celów i zadań edukacji ekologicznej odbywa się w ramach działań zamieszczonych w „Kalendarium Ekologicznym” wydawanym corocznie przez Departament Ochrony Środowiska Urzędu Marszałkowskiego województwa świętokrzyskiego. Obejmuje imprezy o zasięgu światowym, ogólnopolskim oraz regionalnym, a także wykaz instytucji i organizacji biorących udział $w$ ich realizacji.

Głównymi celami edukacji są:

- „podniesienie świadomości ekologicznej wszystkich grup społeczeństwa, polegającej na wykształceniu nawyków wdrażania zrównoważonego rozwoju, dbałości o stan środowiska i oszczędnego korzystania z jego zasobów,

- stworzenie powszechnego dostępu do informacji dotyczących problematyki ochrony środowiska. ${ }^{12 "}$

Zadania edukacji ekologicznej obejmują jednocześnie kształcenie i wychowanie ekologiczne. ${ }^{13} \mathrm{Wdrożenie} \mathrm{tych} \mathrm{celów} \mathrm{warunkowane} \mathrm{jest} \mathrm{głównie} \mathrm{dobrze}$

${ }^{10}$ E. BucHcrc, Kształcenie przyrodnicze w szkole podstawowej. Zielone szkoly. Działalność i możliwości podwyższania skuteczności edukacyjnej. Ośrodek Doskonalenia Nauczycieli, Płock 2005, s. 87-88.

11 E. Buchcıc, Świadomość ekologiczna dorostych a uczestnictwo ich dzieci w zielonych szkołach. [w] Ksztalcenie ekologiczne dorostych. Cichy D. IBE Warszawa 1998, s. 206.

12 Urząd Marszałkowski Województwa Świętokrzyskiego, Departament Ochrony Środowiska 2004: Edukacja ekologiczna w Województwie Świętokrzyskim na rok 2004. Wydawca Marszałek Województwa Świętokrzyskiego Kielce s. 3.

13 I. ŻEBER-DzIKowSKA, Ksztatcenie ekologiczne w dobie XXI wieku - edukacja dla wszystkich. [w:] Edukacja a zrównoważony rozwój w jednoczacej się Europie, red. E. Rydza, A. Kowalaka. Pomorska Akademia Pedagogiczna, Słupsk 2005 s.63 -70. 
funkcjonującą wymianą informacji oraz upowszechnieniem gminnych, powiatowych oraz wojewódzkiego programu ochrony środowiska.

Edukacja Ekologiczna na różnych etapach kształcenia powinna wykształcić u uczniów umiejętności dostrzegania oraz rozumienia obserwowanych zjawisk. Powinna umieć odnieść procesy globalne do środowiska lokalnego i obiektywnie określić swój udział w ich przebiegu. ${ }^{14}$

Cele edukacji ekologicznej można osiągnąć w drodze:

- „edukacji formalnej, obejmującej dzieci od wieku przedszkolnego oraz młodzież po studentów szkół wyższych, a także nauczycieli i specjalistów związanych z ochroną środowiska,

- edukacji nieformalnej, obejmującej młodzież i dorosłych, prowadzonej przez środki masowego przekazu oraz za pomocą różnych form tzw. samoedukacji indywidualnej i grupowej." 15

Edukacją ekologiczną należy objąć wszystkie grupy społeczeństwa, grupy społeczno-zawodowe:

- dzieci, młodzież i dorosłych,

- grupy społeczne (zawodowe),

- uczonych.

Edukacja ekologiczno - środowiskowa prowadzona w gminie Kielce obejmuje swym zasięgiem edukację formalną i nieformalną. Dotyczy ona zarówno młodzież szkolną, jak również społeczność ludzi dorosłych. W wielu placówkach oświatowych znajdujących się na terenie miasta Kielce, począwszy od przedszkoli, poprzez szkoły podstawowe, gimnazja i szkoły ponadgimnazjalne, a skończywszy na wyższych uczelniach, prowadzona jest formalna edukacja ekologiczno środowiskowa.

Najbardziej zaangażowanymi placówkami oświatowymi w dbałość o ochronę środowiska przyrodniczego w mieście, prowadzącymi różnego rodzaju akcje, organizującymi szkolenia, konkursy są:

- Przedszkola Samorządowe, organizujące m.in.:

- konkursy piosenek ekologicznych,

- happening ekologiczny „Wszystko da się wykorzystać”,

- "Obchody Dnia Ochrony Środowiska”,

- akcja „Sprzątanie świata”,

- spartakiada sportowa „Aktywny wypoczynek zgodny z naturą",

- festyn ekologiczny „Ziemia - Wyspa Zielona”,

14 I. ŻEBER-DzIKowsKa, W poszukiwaniu rozwiązań dydaktycznych w edukacji ekologicznej na drugim etapie ksztalcenia. [w:] Edukacja środowiskowa wzmocnieniem zrównoważonego rozwoju. Praca zbiorowa pod red. D. Cichy. IBE,WSP ZNP, Warszawa 2005.str 184-191.

is B. Pоsкrовко, Spoleczne czynniki ochrony środowiska, [w:] K. Górka, B. Poskrobko, W. Radecki, Ochrona środowiska. Polskie Wydawnictwo Ekonomiczne, Warszawa 2001, s. 42. 
- akcja „Dokarmiamy ptaki”,

- akcja „Chronimy kasztanowce”,

- "Święto niezapominajki”,

- quiz „Przyjaciele przyrody”,

- Szkoły Podstawowe, m.in.:

- konkurs ekologiczny „Góry Świętokrzyskie naszym domem”,

- akcja „Nadchodzi zima zwierzęta oczekują twojej pomocy”,

- selektywna zbiórka surowców wtórnych,

- zbiórka makulatury, aluminium, baterii,

- konkurs fotograficzny „Przyroda w obiektywie”,

- konkurs na najpiękniejszy album poświęcony ochronie przyrody,

- Gimnazja, m.in.:

- „Zielony tydzień",

- konkurs „Chemia ratuje czy chroni środowisko”,

- projekt „Ocena stanu środowiska najbliższej okolicy”,

- konkurs plastyczny „Tydzień czystości wód”,

- konkurs literacki „Woda źródłem życia”,

- Zespoły Szkół Ponadgimnazjalnych, m.in.:

- projekt badań „Baltic Sea Project”,

- konkurs ekologiczny „Z ekologią na ty”,

- konkurs wiedzy ekologicznej,

- przegląd małych form teatralnych o tematyce ekologicznej,

- Akademia Świętokrzyska im. Jana Kochanowskiego,

- Wyższa Szkoła Ubezpieczeń,

- Politechnika Świętokrzyska.

Współorganizatorami wyżej wymienionych imprez, konkursów, akcji są Urząd Miasta, Liga Ochrony Przyrody, Polski Klub Ekologiczny, Kieleckie Centrum Kultury oraz wiele innych instytucji, dla których stan środowiska przyrodniczego miasta nie jest obojętny.

Informacja jako czynnik kształtowania świadomości społecznej jest wieloźródłowa. Można wyróżnić następujące źródła informacji ekologicznej:

- instytucjonalną informację masową (środki masowego przekazu, czasopisma specjalistyczne, wydawnictwa nieperiodyczne, plakaty i inne formy propagandy);

- informację pozainstytucjonalną (obserwacje własne, przekazy innych ludzi);

- informację naukową i popularnonaukową (publikacje, raporty, filmy ekologiczne, odczyty i prelekcje);

- informację statystyczną."

16 B. Posкroвко, Spoteczne czynniki ochrony środowiska, [w:] K. Górka, B. Poskrobko, W. Radecki, Ochrona środowiska. Polskie Wydawnictwo Ekonomiczne, Warszawa 2001, s. 46. 
W procesie edukacji nieformalnej największe znaczenie i najszerszy zasięg oddziaływania mają środki masowego przekazu: telewizja, radio, prasa, internet.

W Kielcach dużą rolę w zakresie edukacji nieformalnej odgrywają m.in.:

- telewizja TVP3, gdzie prowadzone są programy poświęcone ekologii, zagrożeniom ekologicznym dla miasta, jak również przekazywane są oglądającym pozytywne działania prowadzone w mieście na rzecz ochrony środowiska,

- prasa, „Metro”, „Echo Dnia”, „Słowo Ludu”, jak również gazetki szkolne, studenckie, w których poruszany jest również problem ochrony środowiska w mieście, działania na rzecz środowiska przyrodniczego oraz jakie imprezy, akcje poświęcone ekologii w najbliższym czasie będą miały miejsce lub te które się już odbyły,

- radio, Radio Kielce S.A., Radio TAK FM, w których prowadzone są proekologiczne audycje, posiadające duże grono słuchaczy,

- plakaty, ulotki, rozdawane na ulicach miasta też odnoszą spodziewane rezultaty,

- internet, w którym na stronach WWW. są dostępne informacje o środowisku w mieście.

Powszechny dostęp do środków masowego przekazu sprawia, że mieszkańcy Kielc posiadają wiedzę na temat ochrony środowiska w mieście. Nie należy jednak zaprzestać edukacji ekologicznej, co więcej należy kłaść jeszcze większy na to nacisk.

Trzeba również zwrócić uwagę na to, iż edukacje formalna i nieformalna powinny być ze sobą połączone i współdziałać. Szkoły nie mogą być wyręczane przez nieformalne ruchy ekologiczne. Działalność edukacyjna nieformalna może, a nawet powinna wspomagać szkoły, a nie wyręczać je i tworzyć oddzielny nurt. Powinna ze szkołami wspólpracować i pomagać im.

Wiele działań praktycznych dotyczących ochrony środowiska podejmują pozarządowe formalne i nieformalne organizacje społeczne. Glównym celem ich działania jest wspieranie ochrony środowiska, popieranie edukacji ekologicznej jak również stymulowanie zrównoważonego rozwoju.

„... do tych, którym powierzona

została odpowiedzialność za ten kraj (...),

aby nie zapomnieli o obowiąku chronienia

go przed ekologicznym zniszczeniem..."

Ojciec Święty Jan Paweł II 


\section{Literatura}

Buchcic E. 1998: Świadomość ekologiczna doroslych a uczestnictwo ich dzieci w zielonych szkołach. [w] Kształcenie ekologiczne dorosłych. Cichy D. IBE Warszawa.

Buchcic E. 2005: Ksztalcenie przyrodnicze w szkole podstawowej. Zielone szkoły. Działalność i możliwości podwyższania skuteczności edukacyjnej. Ośrodek Doskonalenia Nauczycieli Płock.

Cichy D. 2002: Zmiany w edukacji biologicznej i środowiskowej w szkołach ponadgimnazjalnych. Edukacja Biologiczna i Środowiskowa. 1. s.45-48.

Cichy D. 1996: Szkoła ekologiczna. Funkcjonowanie i perspektywy rozwoju. Fundacja Centrum Edukacji Wsi w Krośnie. Krosno.

Dołęga J.M. 2005: Zamiast wprowadzenia. [w] Problemy XXI wieku prawo ochrony środowiska, edukacja środowiskowa i agrobiznes. Czartoszewski J.W.; Grzegorzewicz E.; Ŝwiderski A.W. Wydawnictwo Uniwersytetu Kardynała Stefana Wyszyńskiego Warszawa.

Dubel K. 1996: Inwentaryzacja przyrodnicza gmin w programach ekorozwoju, [w:] Ekorozwój w gminie. Red. Gumińska M. Towarzystwo Naukowe Sandomierskie Sandomierz.

Poskrobko B. 1998: Zarządzanie środowiskiem. Polskie Wydawnictwo Ekonomiczne Warszawa.

Poskrobko B. 2001: Społeczne czynniki ochrony środowiska, [w:] Górka K.; Poskrobko B.; Radecki W. Ochrona środowiska. Polskie Wydawnictwo Ekonomiczne Warszawa.

Urząd Marszałkowski Województwa Świętokrzyskiego, Departament Ochrony Srodowiska 2004: Edukacja ekologiczna w Województwie Świętokrzyskim na rok 2004. Wydawca Marszałek Województwa Świętokrzyskiego Kielce.

Żeber - Dzikowska I. 2005: Kształcenie ekologiczne w dobie XXI wieku - edukacją dla wszystkich.[w:] Edukacja a zrównoważony rozwój w jednoczącej się Europie pod red. E. Rydza, A. Kowalaka. Pomorska Akademia Pedagogiczna, Słupsk.

Żeber - Dzikowska I. 2005: W poszukiwaniu rozwiązań dydaktycznych w edukacji ekologicznej na drugim etapie kształcenia. [w:] Edukacja środowiskowa wzmocnieniem zrównoważonego rozwoju. Praca zbiorowa pod red. D. Cichy. IBE,WSP ZNP, Warszawa.

www.um.kielce.pl/środowisko

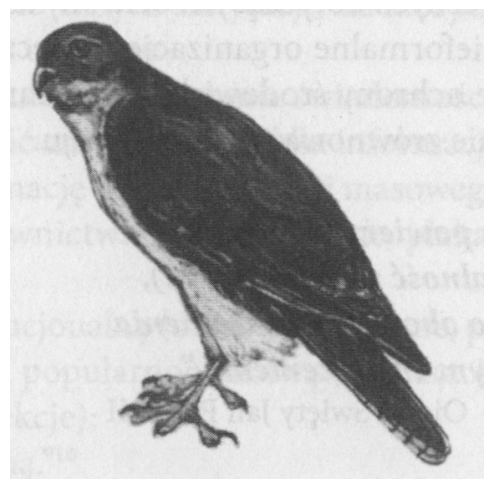

Błotniak zbożowy 